\author{
Research Article \\ www.ijrap.net
}

\title{
ROLE OF NARIKELA LAVANA IN THE MANAGEMENT OF AMLAPITTA
}

Mahajan Roshi ${ }^{*}$, Khanna Vishal ${ }^{2}$, Bhardwaj Ankush ${ }^{3}$

${ }^{1}$ Assistant professor, Department of Rog nidaan, Jammu Institute of Ayurveda and Research, Jammu, J\&K, India

${ }^{2}$ Assistant professor, Department of PG studies in Shalya tantra, Jammu Institute of Ayurveda and Research, Jammu, J\&K, India

${ }^{3}$ Assistant professor, Department of Shalakya tantra, Jammu Institute of Ayurveda and Research, Jammu, J\&K, India

Received on: 01/04/16 Revised on: 11/05/16 Accepted on: 01/06/16

\author{
*Corresponding author \\ E-mail: roshimahajanmd@gmail.com
}

DOI: $10.7897 / 2277-4343.073111$

\begin{abstract}
Amlapitta is a gastrointestinal disorder caused due to suppression of Jatharagni (digestive fire) by increased Drava (watery) and Amla (sourness) gunas of Vidagdha Pachak Pitta (burned digestive enzymes). As the digestion is dependent on the proper functioning of Agni, there is metabolic disequilibrium leading to production of Ama (undigested food). Therefore what so ever food is taken remains undigested and gets changed into shukta (fermented) form and is manifested in the form of Amlapittta. Regarding this disease, a clinical trial having pre and post test design with 30 patients was carried out in Jammu Institute of Ayurveda and Research hospital, Jammu in 2011. Most of the patients with symptoms like tiktaamlodgara, utklesha, aruchi, avipaka, hrit-kantha daha responded well to the treatment. Overall effect of therapy showed the drug is statistically significant and $53.33 \%$ of the patients had and marked relief whereas only $3.33 \%$ patients have shown no relief.
\end{abstract}

Key words: Amlapitta, Jatharagni, Vidagdha, Ama.

\section{INTRODUCTION}

In the last few decades, man has taken great strides in progress. No doubt this transformation brought some good number of benefits but the changes like Introduction of newer and newer food materials, consumption of incompatible, rotten, sour food substances which increase burning sensation, irregular diet pattern, suppression of natural urges, excessive consumption of hot,unctuous, dry food leads to aggravation of vatadi doshas and ultimately causing mildness of agni and just like milk poured into undried and uncleaned curd pot gets fermented ${ }^{1}$. In the same way what so ever food is taken at this time gets improperly processed into rasa dhatu causing amlapitta which is characterised by indigesion, burning senation in the chest and throat, exhaustion, nausea, sour and bitter eructations and heaviness ${ }^{2}$. Along with these factors tremendous stress and strain, disturbed sleep and anxiety have also significantly aggravated the disease ${ }^{3}$. In the recent years, there has been a significant increase in the incidences of Amlapitta presenting a constant challenge to the research workers of Ayurveda.

In Ayurveda, several herbs and formulations have been tried on various aspects of Amlapitta as the herbal drugs have been known to provide a new therapeutic approach in the management of Amlapitta. Narikela lavana has been reported to be an effective remedy in treatment of Amapitta ${ }^{4}$.In this present study, an effort has been made to establish the role of Narikela lavana in the management of Amlapitta

\section{MATERIAL AND METHODS}

This trial involved 30 patients who were randomly selected on the basis of presence of classical symptoms of Amlapitta. Patients were subjected to detailed clinical history, physical and lab investigations on the basis of specially prepared Performa.
Prior consent was taken from the patients after explaining the details regarding the treatment.

\section{Inclusion criteria}

- Patients of age between 15 and 50 years.

- Patients having classical symptoms of Amlapitta.

Exclusion criteria

- Patients with peptic ulcer, cholelithiasis, haematemesis, malena etc.

- Patients with other concomitant disorders requiring NSAIDS and steroids for treatment.

- Chronicity more than 5 years.

- Patients with other diseases like angina pectoris, diabetes, HT, CHD.

\section{Criteria for assessment}

The clinical signs and symptoms were assessed by adopting the scoring method in pattern of 0 (absent), 1 (mild), 2 (moderate)and 3 (severe). Subjective and objective parameters of baseline data to pre and post medication were compared for the assessment of results. All the results were analysed statistically by student paired $-t$ test. The total effect of the therapy was assessed considering the following criteria:

- Complete remission: $100 \%$ relief in the sign and symptoms was considered as complete remission.

- Markedly improved: More than $75 \%$ relief in the sign and symptoms was considered as marked improvement.

- Moderately improved: $51-75 \%$ relief in the sign and symptoms was considered as mild improvement.

- Unchanged: Relief below $25 \%$ was considered as unchanged. 


\section{Method of preparation of drug}

\section{Ingredients of Narikela lavana}

\begin{tabular}{|c|c|c|c|}
\hline S.No & Drug Name & Botanical Name & Quantity \\
\hline 1. & Narikela fruit & Cocos nucifera & 1 \\
\hline 2. & Saindhav Lavana & Rock salt & $120 \mathrm{~g} /$ narikela \\
\hline
\end{tabular}

The ingredients mentioned in above table were taken. Firstly the coir of the narikela was peeled off and its eye was pierced, then $120 \mathrm{~g}$ of Saindhav lavana was filled in each narikela. Then it was concealed with a lepa of Mash dal and left to dry. After it has dried it was again shielded with seven kapad mitti and left to dry. Later after drying they were given a gaja-puta. After the fire doused by itself, the narikela were taken out and lavana was obtained.

\section{Drug Schedule}

Drug : Narikela lavana Churana orally

Dose : $: 250 \mathrm{mg}$ was given twice a day

Anupana : Luke warm Water

Duration : 60 days

The patients were advised for follow up at an interval of 15 days for three months.

\section{OBSERVATIONS AND RESULTS}

Effect of therapies on Tikta-Amlodgara

\begin{tabular}{|c|c|c|c|c|c|c|c|}
\hline $\begin{array}{c}\text { Mean } \\
\text { B.T }\end{array}$ & $\begin{array}{c}\text { Mean } \\
\text { A.T }\end{array}$ & $\begin{array}{c}\text { Mean } \\
\text { Difference }\end{array}$ & $\begin{array}{c}\text { \% } \\
\text { Relief }\end{array}$ & S.D & S.E & T value & P value \\
\hline 3.0 & .28 & 2.72 & 90.66 & 0.89 & 0.18 & 15.27 & $<0.001$ \\
\hline
\end{tabular}

The mean of B.T. was 3.0, while that of A.T. was .28 It showed $90.66 \%$ relief and statistically it is highly significant at $\mathrm{p}<0.001$.

\section{Effect of therapies on Hritkanthadaha}

\begin{tabular}{|c|c|c|c|c|c|c|c|}
\hline $\begin{array}{c}\text { Mean } \\
\text { B.T }\end{array}$ & $\begin{array}{c}\text { Mean } \\
\text { A.T }\end{array}$ & $\begin{array}{c}\text { Mean } \\
\text { Difference }\end{array}$ & $\begin{array}{c}\text { \% } \\
\text { Relief }\end{array}$ & S.D & S.E & t value & P value \\
\hline 2.4 & 1.1 & 1.3 & 54.16 & 0.75 & 0.15 & 8.43 & $<0.001$ \\
\hline
\end{tabular}

The mean of B.T. was 2.4, while that of A.T. was 1.1. It showed $54.16 \%$ relief and statistically it is highly significant at $p<0.001$

Effect of therapies on Aruchi

\begin{tabular}{|c|c|c|c|c|c|c|c|}
\hline $\begin{array}{c}\text { Mean } \\
\text { B.T }\end{array}$ & $\begin{array}{c}\text { Mean } \\
\text { A.T }\end{array}$ & $\begin{array}{c}\text { Mean } \\
\text { Difference }\end{array}$ & $\begin{array}{c}\text { \% } \\
\text { Relief }\end{array}$ & S.D & S.E & t value & P value \\
\hline 2.86 & 0.238 & 2.62 & 91.67 & 0.80 & 0.17 & 14.914 & $<0.001$ \\
\hline
\end{tabular}

The mean of B.T. was 2.86 , while that of A.T. was 0.238 . It showed $91.67 \%$ relief and statistically it is highly significant at $\mathrm{p}<0.001$

Effect of therapies on Avipaka

\begin{tabular}{|c|c|c|c|c|c|c|c|}
\hline $\begin{array}{c}\text { Mean } \\
\text { B.T }\end{array}$ & $\begin{array}{c}\text { Mean } \\
\text { A.T }\end{array}$ & $\begin{array}{c}\text { Mean } \\
\text { Difference }\end{array}$ & $\begin{array}{c}\text { \% } \\
\text { Relief }\end{array}$ & S.D & S.E & P value & P value \\
\hline 2.75 & 0.33 & 2.42 & $88 \%$ & 0.93 & 0.19 & 12.75 & $<0.001$ \\
\hline
\end{tabular}

The mean of B.T. was 2.75 , while that of A.T. was 0.33 . It showed $88 \%$ relief and statistically it is highly significant at $\mathrm{p}<0.001$.

\section{Effect of therapies on Utklesha}

\begin{tabular}{|c|c|c|c|c|c|c|c|}
\hline $\begin{array}{c}\text { Mean } \\
\text { B.T }\end{array}$ & $\begin{array}{c}\text { Mean } \\
\text { A.T }\end{array}$ & $\begin{array}{c}\text { Mean } \\
\text { Difference }\end{array}$ & $\begin{array}{c}\text { \%o } \\
\text { Relief }\end{array}$ & S.D & S.E & t value & P value \\
\hline 2.53 & .31 & 2.2 & 87.74 & 1.03 & 0.24 & 9.34 & $<0.001$ \\
\hline
\end{tabular}

The mean of B.T. was 2.53 , while that of A.T. was 0.31 . It showed $87.74 \%$ relief and statistically it is highly significant at $\mathrm{p}<0.001$.

\section{Overall effect of therapy}

$53.33 \%$ of the total patients showed marked improvement. $33.33 \%$ of the total patients showed moderate improvement. Mild relief was seen in $10 \%$ patients. In only $3.33 \%$ patients, no relief was seen.

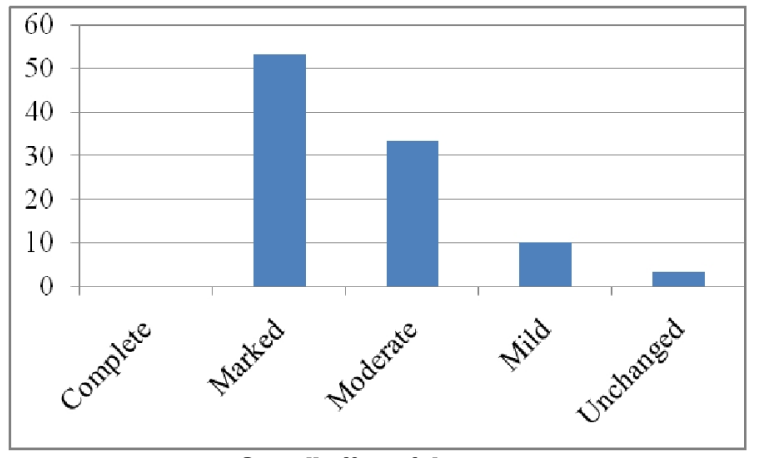

Overall effect of therapy 


\section{DISCUSSION}

Based on the observations, majority of the patients were between 30 to 39 years of age group. More incidences were observed in male patients i.e. about $65.85 \%$ and is probably due to the consumption of fast food and also occupational stress. $86.66 \%$ patients were married and it may be said that the married persons are more prone to stress, anxiety and other family problems. Prakriti wise distribution shows $40 \%$ Vatapittaj Prakriti, 33.33\% of Pitta-kaphaj Prakriti and $26.66 \%$ of people are of Vata-kaphaj prakriti. This show all the Prakriti groups are equally affected, but specially Vata-pittaj Prakriti patients are more prone to Amlapitta. Nidana of Amlapitta clears that is a disorder caused not only by irregular diet schedule but also as a result of physiological and psychological aberrations ${ }^{5}$. The increasing rate of Amlapitta presents a constant challenge to research workers of Ayurveda. Treatment therapy observed a statistically significant relief in the symptoms of tikta-amlodgara, hritkanthadaha, aruchi, avipaka and utklesha. The Probable mode of action of the drug may be explained on the basis of its pitta shamak properties as the disease is pitta dosha dominant vyadhi. Both the drugs in Narikela Lavana yoga are Shita Virya and Madhura vipaka ${ }^{6}$. These properties pacify the Pitta dosha and thus help in relieving the symptoms of Amlapitta.Madhura rasa of Narikela pacifies the Pitta Dosha ${ }^{7}$. Daha produced in Amlapitta quickly mitigates by the virtue of its sheet virya. Moreover, in Amlapitta, mainly there is vitiation of Annavaha srotasa. Agnimandya is the due cause of Amlapitta which also produces Ama. Lavana has Ama Pachaka property which helps in digesting Ama quickly ${ }^{8}$. These drugs have Anulomaka, daha shamaka, and pachana properties which act on the vitiated srotas .Moreover; the Madhura rasa purifies the srotasa through their Sroto shuddhikara property. Ghosh Kuntal et al in their clinical observational work also mentioned the fruitful result of drugs having madhur rasa and sheet virya in the disease.Amlapitta.

\section{CONCLUSION}

Narikela lavana is an effective remedy in uncomplicated and new cases of amlapitta. But it has played a limited role in management of chronic cases of amlapitta. Administration of Narikela lavana has yielded highly significant result. Thus, it can be stated that the Narikela Lavana is an effective drug for Amlapitta.

\section{Further scope for research}

As the present study was conducted over 30 patients, a similar study may be performed over a large sample for longer duration to obtain more accurate results

\section{REFERENCES}

1. Prof. ( Km) P.V Tewari, Kashyapa samhita- khilasthana, 16, by MaharshiMaricha Kashyapa, chaukambhavisvabharati 2008

2. Madhava: Madhava Nidanam with com-mentaries The Madhukosa of Srivijayarak-shita and srikanthadatta with The Viyotini Hindi Commentay and Notes edited by Prof. Yadunandana Upadhyaya, Chauk-hambha Prakashan, Varanasi, Chapter 51 Verse 2-12, Edi. Reprint (2007) p1712.

3. Agnivesha: Charaka samhita,revised by charak and Dridhabal, with commentary of chakrapanidatta, edited by jadavji trikamji acharya, chaukhambha Sanskrit Sansthana, Varanasi. Sutra Sthana, Chapter 26 verse 100, 5th Edi.page

4. Sadananda Sharma - Rasatarangini 14th Taranga, 11th edi Published by Shri Jainendra press, New Delhi, 1994 Pg.No.347-348

5. VJ TrikamjiAcharya,CarakaSamhita by Agnivesa revised by Caraka and Dridhabala with the Ayurveda Dipika Commentary of Chakrapanidatta,Chaukambha Prakashan,2013.

6. Sharma PV. Dravya Guna Vignana (vegetable drug).14th ed, Varanasi; Chauk-hambha Bharathi academic: 1993, .pg no. 117.

7. Sushruta: Sushrut samhita, with com- mentary of dalhana, edited by vaidya jadavji Trikamji Acharya, Chaukhambha Surbharti Prakashan, Varanasi 8th edition, Sutra sthana, chapter 45, verse, Re- print (2010) p172.

8. Agnivesha: Charaka samhita,revised by charak and Dridhabal, with commentary of chakrapanidatta, edited by jadavji trikamji acharya, chaukhambha Sanskrit Sansthana, Varanasi. Sutra Sthana, Chapter 27 verse 300, 5th Edi.page 412.

9. Ghosh Kuntal et al. Review of clinical observational studies conducted on 1812 patients of amlapitta at I.P.G.T. \& R.A. Jamnagar. Int. J. Res. Ayurveda Pharm. 2011;2 (5):14101415.

\section{Cite this article as:}

Mahajan Roshi, Khanna Vishal, Bhardwaj Ankush. Role of narikela lavana in the management of amlapitta. Int. J. Res. Ayurveda Pharm. May - Jun 2016;7(3): 50-52 http://dx.doi.org/10.7897/2277-4343.073111

Disclaimer: IJRAP is solely owned by Moksha Publishing House - A non-profit publishing house, dedicated to publish quality research, while every effort has been taken to verify the accuracy of the content published in our Journal. IJRAP cannot accept any responsibility or liability for the site content and articles published. The views expressed in articles by our contributing authors are not necessarily those of IJRAP editor or editorial board members. 